\title{
NOTE
}

\section{EXTRATERRITORIAL SUBSIDIARY JURISDICTION}

INTRODUCTION

The Soviet pipeline incident ${ }^{1}$ in 1982 emphasized the conflicting international views toward the exercise of jurisdiction over foreign subsidiaries through parent companies. The validity of subsidiary jurisdiction has become an important issue because of the increasing amount of economic interaction and interdependence between states. The view of some states that no form of extraterritorial subsidiary jurisdiction is acceptable fails to take adequate account of a parent company's power to exercise control over its subsidiaries. Contrastingly, the opposing view that subsidiaries are jurisdictionally indistinguishable from their parents is too broad. International law should provide a compromise that satisfies the major concerns of states holding both views. Section 414[418] of the Restatement (Revised) of the Foreign Relations Law of the United States ${ }^{2}$ provides such a compromise because it authorizes only limited exercises of jurisdiction over foreign subsidiaries.

This note examines the exercise of extraterritorial jurisdiction over foreign subsidiaries through parent companies. Part II provides a brief summary of the traditional bases for jurisdiction and examines current international attitudes toward extraterritorial subsidiary jurisdiction. That section also presents the Soviet pipeline incident as an example of an inappropriate exercise of jurisdiction by the United States. Part III examines section 414 [418] of the Restatement (Revised) which provides an excellent approach to the problem of subsidiary jurisdiction. Section 414[418] provides a viable model of international standards for the exercise of subsidiary jurisdiction because it emphasizes the limited role that subsidiary jurisdiction should play. Part IV offers a working solution to the problem of subsidiary jurisdiction. Because of the current tensions surrounding extraterritorial subsidiary jurisdiction, this note concludes that states should negotiate bilateral treaties. Recognizing that treaties are a long-term solution which may take a considerable period of time to finalize, this note proposes that notification and consultation procedures be adopted during the interim period.

Copyright (C) 1988 by Law and Contempoary Problems

1. See infra notes 19-47 and accompanying text.

2. Restatement (Revised) of the Foreign Relations Law of the United States \$ 414[418] (Tent. Draft No. 6, 1985) [hereinafter Restatement (ReviSed)]. 
II

\section{Subsidiary Jurisdiction: Perspectives and Problems}

\section{A. Jurisdictional Bases}

There is no single basis for jurisdiction in international law that has received universal acceptance. In general, states attempt to exert as much jurisdiction as is feasible. Most states are convinced that they have the right to control virtually everything within their borders, as well as activities that have an effect within their borders. They also attempt to exert influence over the activities of their nationals in other states. This section will provide a brief summary of the recognized bases of extraterritorial jurisdiction. ${ }^{3}$

The most traditional and widely accepted basis for jurisdiction is the territorial principle. ${ }^{4}$ Under the territorial principle, a state has jurisdiction to prescribe laws pertaining to activities or failures to act within its territory. ${ }^{5}$ Because there is now so much economic intercourse and interdependence between states, it is questionable whether the territorial principle can continue to serve as the primary jurisdictional basis in the subsidiary context. Many corporations have established subsidiaries in foreign States. The territorial principle does not respond adequately to conflicts of jurisdiction arising from these arrangements because it fails to recognize that both the home and host state may have legitimate reasons for exercising jurisdiction. There are many instances in which a strictly territorial analysis is too inflexible and therefore does not provide a satisfactory solution.

The "effects" doctrine, a derivative of the territorial principle, is sometimes employed by states. ${ }^{6}$ This doctrine authorizes a state to exercise jurisdiction over individuals and activities occurring outside the state's territorial limits because of illegal or unacceptable consequences within the state. ${ }^{7}$ The "effects" doctrine arises primarily in antitrust cases. For example, the United States has used this doctrine in antitrust cases to impose liability on individuals or companies whose actions outside the United States produce anti-competitive effects within the United States. ${ }^{8}$ In addition, the German antitrust statute explicitly applies to all restraints of competition which have an effect within the territorial scope of the statute-even when the restraints

3. See, e.g., Marcuss \& Richard, Extraterritorial Jurisdiction in United States Trade Law: The Need for a Consistent Theory, 20 Colum. J. Transnat'l L. 439, 440-47 (1981); Feinberg, Economic Coercion and Economic Sanctions: The Expansion of United States Extraterritorial Jurisdiction, 30 AM. U.L. REv. 323, 32633 (1981).

4. See Thompson, United States Jurisdiction Over Foreign Subsidiaries: Corporate and International Law Aspects, 15 L. \& Pol'y Int'l Bus. 319,363 (1983).

5. Restatement (Second) of Foreign Relations Law of the United States $\$ 17$ (1965).

6. The "effects" test for jurisdiction was first articulated in United States v. Aluminum Co. of Am., 148 F.2d 416,443 (2nd Cir. 1945) (the Alcoa case).

7. See, e.g., id.; Continental Ore Co. v. Union Carbide and Carbon Corp., 370 U.S. 690, 704 (1962); In re Uranium Antitrust Litig., 617 F.2d 1248, 1253-54 (7th Cir. 1980); Rivard v. United States, 375 F.2d 882, 886 (5th Cir. 1967), cert. denied, 389 U.S. 884 (1967); Zenith Radio Corp. v. Matsushita Elec. Indus. Co., 494 F. Supp. 1161, 1177 (E.D. Pa. 1980).

8. United States v. Aluminum Co. of Am., 148 F.2d 416 (2d Cir. 1945). 
occur outside the statute's territorial scope. 9 Thus, the "effects" doctrine brings individuals or companies within the territorial power of the state by focusing on the location of the effects of their conduct. The location of the company or the activities in question is irrelevant for jurisdictional purposes under this doctrine. "This is the most controversial of the territorial-related exercises of jurisdiction; it has provoked great debate when applied in antitrust cases and has not been widely accepted by other states." 10

The nationality principle authorizes a state to exercise jurisdiction over its own nationals regardless of whether they are inside or outside of the state's territory. Attempts to exert jurisdiction over foreign subsidiaries under this principle depend on the nationality of either the parent or the subsidiary." U.S. law generally views corporations as nationals of the state of incorporation. Some European countries also look to the principal place of business or the center of activities. ${ }^{12}$

The security or protective principle allows a state to prosecute aliens whose actions outside the territorial limits of the state threaten or harm the security or independence of the state. ${ }^{13}$ The passive personality principle is similar to the security principle in that it grants jurisdiction over aliens who commit extraterritorial acts against the state's nationals. ${ }^{14}$ Finally, the universality principle authorizes states to punish aliens for crimes, such as piracy, which violate "international public policy." 15

\section{B. The Soviet Pipeline Incident}

The United States has acted more aggressively than other states with regard to jurisdiction over foreign subsidiaries. Claims of jurisdiction over foreign subsidiaries by the United States do not fit directly under any of the bases for jurisdiction set forth above. ${ }^{16}$ The United States has consistently treated foreign subsidiaries as though they were branches of domestic corporations. It has frequently ignored the separate legal status of foreign subsidiaries and has attempted to exert jurisdiction over them based on control or share ownership by U.S. parent companies. Unilateral jurisdictional extensions by the United States have had significant

9. Many European countries are vehemently opposed to the "effects" doctrine, but others have started incorporating it into their legal systems. See Gesetz gegen Wettbewerbsbeschränkungen, 1957 Bundesgesetzblatt [BGB1] I 1081 \& 98(2) (July 27) (translation available in Gerber, The Extraterritorial Application of the German Antitrust Laws, 77 AM. J. INT'L L. 756, 760 (1983)).

10. Thompson, supra note 4, at 363. See generally Nash, Contemporary Practice of the United States Relating to International Law, 74 AM. J. INT'L L. 657 (1980).

11. For a summary of the criteria used to determine the nationality of a corporation, see Note, Extraterritorial Application of United States Law: The Case of Export Controls, 132 U. PA. L. REv. 355, 372-75 (1984).

12. See Thompson, supra note 4 , at 364 .

13. See Marcuss \& Richard, supra note 3, at $\mathbf{4 4 5 .}$

14. Id. at 447 .

15. Id.

16. See Thompson, supra note 4 , at 363 . 
international repercussions ${ }^{17}$ and created many conflicts. ${ }^{18}$ The Soviet pipeline incident is an example of one such jurisdictional extension contributing to the international tension in this area. ${ }^{19}$

On June 22, 1982, the United States established an export embargo prohibiting the re-export of oil and gas equipment (that utilized U.S. goods or technology) to the Soviet Union from third countries. ${ }^{20}$ These regulations prohibited foreign subsidiaries of U.S. companies from selling oil and gas equipment to the Soviet Union, and from selling these goods to any parties who in turn sold them to the Soviet Union. ${ }^{21}$ The embargo was imposed to cause economic injury to the Soviet Union in order to advance reconciliation in Poland by discouraging Soviet interference there. ${ }^{22}$ The United States claimed jurisdiction over foreign subsidiaries because they were either owned or controlled by persons or corporations subject to U.S. jurisdiction. ${ }^{23}$ European governments reacted violently to this action because they felt the United States had violated international law. ${ }^{24}$ Although the controversy was eventually mooted when President Reagan lifted the sanctions in November, $1982,{ }^{25}$ the underlying tensions were not resolved.

The most serious tactical error committed by the U.S. was its failure to include a grandfather clause in the regulations to prevent a retroactive effect on existing contracts. Because of this error, both compliance and noncompliance with the U.S. export regulations exposed foreign subsidiaries to undesirable consequences. ${ }^{26}$ Compliance with the regulations would have caused subsidiaries to lose immediate income, to breach outstanding contracts, and to risk the loss of future sales. Noncompliance, however, would have caused the subsidiary to lose its U.S. export privileges and licenses. This loss, in turn, would have hurt those subsidiaries that devoted a large portion of their other business to the export of U.S. licensed products.

17. For discussion of the Soviet pipeline incident, see infra text accompanying notes 19-26. See also Tittmann, Extraterritorial Application of U.S. Export Control Laws on Foreign Subsidiaries of U.S. Corporations: An American Lawyer's View from Europe, 16 INT'L LAw. 730, 733-36 (1982); Zaucha, The Soviet Pipeline Sanctions: The Extraterritorial Application of U.S. Export Controls, 15 L. \& PoL'y INT'L BUS. $1169,1173-78$ (1983).

18. For an excellent discussion of historical examples of the application of U.S. laws to foreign subsidiaries, see Thompson, supra note 4, at 322-61.

19. The procedural details of the incident have been catalogued by a number of commentators. See, e.g., Merciai, The Euro-Siberian Gas Pipeline Dispute-A Compelling Case for the Adoption of Jurisdictional Codes of Conduct, 8 MD. J. INT'L L. \& Trade 1, 10-13 (1984); Thompson, supra note 4, at 354-56.

20. 15 C.F.R. $\$ 385.2$ (c) (1985).

21. The regulations also prohibited non-U.S. companies from selling U.S. oil and gas equipment to the Soviet Union.

22. See infra text accompanying notes 63-67.

23. See Note, Dresser Industries: The Failure of Foreign Policy Trade Controls Under the Export Administration Act, 8 MD. J. INT'L L. \& Trade 122, 127-29 (1984).

24. See generally European Communities: Comments on the U.S. Regulations Concerning Trade with the U.S.S.R., reprinted in 21 InT'L Legal Materials 891 (1982). See Common Market Challenges U.S. Policies on Trade as Economic Relations Worsen, Wall St. J., July 1, 1982, at 4, col. 2; Canada May Challenge Sanctions Set by U.S. on Soviet Pipeline, Wall St. J., Aug. 10, 1982, at 42, col. 1.

25. Revision of Export Controls Affecting the U.S.S.R. and Poland, 47 Fed. Reg. 51,858 (1982) (codified at 15 C.F.R. $\$ \S 379,385,390,399(1982)$ ).

26. See Note, supra note 11 , at 368 . 
The solution seized upon by affected companies was to seek a judicial resolution favorable to their position.

In clashes of extraterritorial jurisdiction, each state generally wins in its own courts. ${ }^{27}$ Dresser Industries, Inc. $v$. Baldridge ${ }^{28}$ and Compagnie Europeenne des Petroles S.A. v. Sensor Nederland B.V. ${ }^{29}$ illustrate this point. The plaintiff in Dresser Industries was a French subsidiary of a U.S. parent company. It sought injunctive relief in a U.S. district court from an order issued by the Hearing Commissioner of the International Trade Administration that had revoked all of the outstanding U.S. export licenses of Dresser (France) ${ }^{30}$ This order was issued after Dresser (France) violated the export restrictions by shipping three natural gas compressors to the Soviet Union as required by contract. ${ }^{31}$ The district court refused to grant injunctive relief from the temporary denial order because Dresser (France) failed to satisfy the standard requirements for an injunction. ${ }^{32}$ The court held that Dresser (France) had not made a strong showing that it was likely to prevail on the merits, and the continuing availability of administrative remedies eliminated the possibility of irreparable harm. The court also stated that the regulations were "promulgated as part of a major foreign policy exercise," suggesting that this action was one with which courts should not interfere. ${ }^{33}$ The court's conclusion that the regulations were primarily political was justified. As an American court, it would have to follow the clear directives of the United States Government if the regulations were intended to cover the type of transaction at issue and were valid under the United States Constitution. ${ }^{34}$ As both of these conditions were satisfied, the court could not engage in an independent evaluation of the merits of the regulations.

Plaintiff C.E.P. in Sensor Nederland was a French company which had contracted with Sensor Nederland B.A. for pipeline products destined for the Soviet Union. Sensor was domiciled in the Netherlands and it was a one hundred percent subsidiary of another Netherlands company, Geosource

27. Ultimately, the foreign state is more likely to prevail. Id. See also Vagts, The Global Corporation and International Law, 6 J. INT'L L. \& ECoN. 247, 256 (1972). Professor Vagts points out that the United States has repeatedly recognized that when its mandate encounters a contradictory compulsion from a foreign state, its rule based on nationality or control must necessarily give way.

28. 549 F. Supp. 108 (D. D.C. 1982). For a discussion of this case, see Note, supra note 23.

29. Compagnie Europeenne Des Petroles v. Sensor Nederland, reprinted in 22 INT'L LEGAL Materials 66 (1983) (a District Court at the Hague Judgment, 1982).

30. The Commissioner's order was later modified to cover only the licenses of goods relating to oil and gas technology. In re Dresser (France), Case No. 652, Order Modifying Temporary Denial of Export Privileges, U.S. Department of Commerce, I.T.A. (Sept. 7, 1983), at 3.

31. See Oberdorfer, Equipment is Shipped to Soviets, Wash. Post, Aug. 27, 1982, at A1, col. 6.

32. Dresser Indus. v. Baldridge, 549 F. Supp. 108, 110 (D. D.C. 1982). The requirements for injunctive relief were enunciated in Washington Metro. Area Transit Comm'n v. Holiday Tours, Inc., 559 F.2d 841,843 (D.C. Cir. 1977). The court held that it must inquire (1) whether the movant has made a strong showing that it is likely to prevail on the merits of the case, (2) whether the movant has shown that without such relief, it will be irreparably injured, (3) whether the issuance of an injunction would substantially harm other parties interested in the proceedings, and (4) where the public interest lies. Id.

33. Dresser, 549 F. Supp. at 110.

34. United States v. Aluminum Co. of Am., 148 F.2d 416, 443 (2d Cir. 1945). 
International B.V.. Geosource International, in turn, was a one hundred percent subsidiary of Geosource Inc., an American corporation. Sensor informed C.E.P. that it would not complete delivery of the contract because, as a subsidiary of an American corporation, it was bound by the export embargo of June 22, 1982. C.E.P. brought suit in the District Court at The Hague seeking specific performance of the contract or damages. ${ }^{35}$

The court considered various bases for American jurisdiction and concluded that the Netherland courts did not have to recognize the American embargo. ${ }^{36}$ The court first stated that the contract between C.E.P. and Sensor was governed by Netherlands law. It then found that Sensor had Netherlands nationality both under international law and the March 27, 1956, Treaty of Friendship, Commerce, and Navigation between the Netherlands and the United States because Sensor was organized in the Netherlands and had its center of administration there. ${ }^{37}$ The court held that American jurisdiction was not justified by the "nationality principle" because the United States had attempted to bring within its scope foreign companies. It also rejected American jurisdiction under the "protection principle," reasoning that the protection principle applies to acts jeopardizing the security or creditworthiness of the United States, and "do[es] not include the foreign policy interest that the U.S. measure [sought] to protect." 38 Finally, the court dismissed the possibility of American jurisdiction under the "effects doctrine" because the exportation covered by the embargo did not have direct and illicit effects within the territory of the United States. The court therefore ordered Sensor either to comply with the contract or to pay C.E.P. per diem damages for each day after October 18, 1982, on which Sensor did not make delivery. ${ }^{39}$

Both Dresser Industries and Sensor Nederland show normal judicial reactions to extraterritorial extensions of jurisdiction. The results are not surprising because each court owes a certain amount of allegiance to its own system. ${ }^{40} \mathrm{~A}$ domestic court is not entirely free to evaluate independently the merits of laws passed by the legislative body of its state. If the law is explicit, a domestic court must apply it despite its own views on the substantive issues. In decisions in which the law is less specific, such as those applying the Sherman Act, a domestic court has greater freedom to construe these laws in a manner

35. 22 Int'l Legal Materials 68 (1983).

36. Id. at $72-73$.

37. Id. at 71. The conclusion that Sensor was a Netherlands company is consistent with the conclusion reached by the United States Supreme Court when faced with a similar situation. In Sumitomo Shoji Am., Inc. v. Avagliano, 457 U.S. 176 (1982), the Supreme Court held that the protections of a treaty between Japan and the United States could not be used as a defense in a Title VII suit brought against a wholly owned Japanese subsidiary. The Supreme Court held that the treaty protections extended only to Japanese companies operating in the United States. A wholly owned Japanese subsidiary that was incorporated in the United States was a U.S. corporation and therefore subject to U.S. laws. Id. at 188 .

38. 22 Int'l Legal Materials 68, 72 (1983).

39. Id. at 74 .

40. See Meessen, Antitrust Jurisdiction L'nder Customan International Law', 78 AM. J. INT'L L. 783,787 (1984). "[T] political branches of their respective states, however conflicting they might happen to be." Id. 
consistent with its own views of the legislative intent. Judge Learned Hand, applying the Sherman Act in United States v. Aluminum Co. of America, ${ }^{41}$ accurately summarized these ideas:

[T] he only question is whether Congress intended to impose the liability and whether our own Constitution permitted it to do so: as a court of the United States we cannot look beyond our own law. Nevertheless, it is quite true that we are not to read general words, such as those in this [the Sherman] Act, without regard to the limitations customarily observed by nations upon the exercise of their powers. . . ${ }^{42}$

The courts of a neutral state or the foreign State in which a subsidiary is located will generally show hostility towards extraterritorial extensions. One reason for this hostility is the prevailing view in international law that many extraterritorial extensions are invalid. ${ }^{43}$ In addition, foreign courts, particularly in neutral states, may not want to establish precedents which approve and uphold extraterritorial extensions of jurisdiction because their decisions may adversely affect the rights of their own state's nationals or companies in future suits. Because of the bias against extraterritorial legislation, states should fashion extraterritorial acts carefully to ensure enforcement of these acts by foreign courts.

An analysis of the Soviet pipeline incident shows that the United States failed to consider the possible consequences of exercising jurisdiction over foreign subsidiaries. The United States should have sculptured its aggressive extension of jurisdiction carefully, paying particular attention to the potential conflicts that undoubtedly would arise. The incident substantially weakened the position of the United States on extraterritorial jurisdiction over foreign subsidiaries. ${ }^{44}$ It also provoked universal criticism from European governments and commentators. ${ }^{45}$

The more serious problem, however, is the alienating effect that this incident has had on U.S. relationships with its allies. "We cannot afford a repetition of the pipeline fiasco, a fiasco that damaged the Western alliance far more than it hurt the Russians." 46 Foreign States have responded to past U.S. extraterritorial extensions with mechanisms designed to preserve their jurisdiction. Blocking statutes are an example of one such mechanism. ${ }^{47}$ The Soviet pipeline incident has renewed interest in these options, and has provoked a general feeling of hostility in international relations. The United

41. United States v. Aluminum Co. of Am., 148 F.2d 416, 443 (2d Cir. 1945).

42. Id.; see supra text accompanying notes 36-41.

43. Havers, Good Fences Made Good Neighbors: A Discussion of Problems Conceming the Exercise of Jurisdiction, 17 INT'L LAW. 784, 788 (1983).

44. Furthermore, a government study concluded that most of the pipeline equipment could be purchased from non-U.S. sources, and therefore even a successful embargo would have had only a de minimis effect on the Soviet Union. See Note, Dresser Industries, supra note 23, at 137.

45. See Havers, supra note 43, at 792-93.

46. See Havers, supra note 43, at 792. See also Tittmann, supra note 17, at 733-36.

47. Blocking statutes give a state the right to prohibit its nationals from furnishing commercial information to a court or other authority in another state. For an excellent summary of blocking laws, see Batista, Confronting Foreign "Blocking" Legislation: A Guide to Securing Disclosure from .Von-resident Parties to American Litigation, 17 InT'L LAw. 61, 62-72 (1983). See also Rosen, The Protection of Trading Interests Act, 15 InT'L LAW. 213, 224-28 (1981) (United Kingdom law). 
States has placed foreign States on the defensive and these foreign states now feel they must aggressively protect their own interests. In short, a spirit of self-protection, and not cooperation, dominates international relations.

\section{III}

\section{The Approach of the American Law Institute in the Restatement (REvised)}

Section 414[418] of the Restatement (Revised) contains provisions relating to the exercise of extraterritorial jurisdiction on the basis of intercorporate affiliation. It reads:

$\S 414[418]$. Jurisdiction with Respect to Activities of Foreign Branches and Subsidiaries

(1) Subject to $\S \S 403$ and 436 , a state may exercise limited jurisdiction with respect to activities of foreign branches of corporations organized under its laws.

(2) A state may not ordinarily exercise jurisdiction with respect to activities of corporations organized under the laws of a foreign state on the basis that they are owned or controlled by nationals of the state exercising jurisdiction. However, subject to $\S \S 403$ and 436 , it may not be unreasonable for a state to exercise limited jurisdiction with respect to activities of foreign entities

(a) by direction to the parent corporation in respect of such matters as uniform accounting, disclosure to investors, or preparation of consolidated tax returns of multinational enterprises; or

(b) by direction to the parent or the subsidiary in other exceptional cases, depending on all relevant factors, including:

(i) whether the regulation is essential to implementation of a program to further a major, urgent national interest of the state exercising jurisdiction;

(ii) whether the national program of which the regulation is a part cannot be carried out effectively unless it is applied also to foreign subsidiaries;

(iii) whether the regulation is in potential or actual conflict with the law or policy of the state where the subsidiary is established; and

(c) in the exceptional cases referred to in paragraph (b), the burden of establishing reasonableness is heavier when the direction is issued to the foreign subsidiary than when issued to the parent corporation. ${ }^{48}$

Section 414[418] applies only to jurisdiction exercised on the basis of intercorporate affiliation, and does not affect the exercise of jurisdiction on other bases. ${ }^{49}$ The provisions of sections 403 and 436 are applicable to exercises of jurisdiction over branches or subsidiaries. Section 403 spells out the criteria for evaluating reasonableness. ${ }^{50}$ Section 436 contains specific provisions relating to conflicting directives issued to nationals living abroad by the home and the host state. ${ }^{51}$ This note will assume that the requirements of sections 403 and 436 have been satisfied and will proceed to examine the additional requirements in section $414[418]$.

The key to interpreting section 414[418] is contained in the limiting language within the individual subsections. If these limitations are not

48. RESTATEMENT (REvised) supra note $2, \$ 414[418]$.

49. Id. comment a, at 230-32.

50. Id. $\S 403$.

51. Id. § $436[419]$. 
followed strictly, it is likely that the resulting extensions of U.S. jurisdiction will lead to another international fiasco like the Soviet pipeline incident.

Subsection (1) authorizes a state to exercise limited jurisdiction over the activities of foreign branches of corporations organized under its law. ${ }^{52}$ Although the home state must respect the jurisdiction of the foreign State, international law recognizes that the exercise of jurisdiction by the home state is appropriate in some situations. This subsection shows proper deference to this international principle by specifying that the home state may exercise only "limited" jurisdiction. Faithful adherence to this principle should substantially reduce disagreement. For example, most foreign States would accept the prescription of U.S. antipollution standards on the production of automobiles by foreign branches of U.S. automotive manufacturers for sale in the foreign State. They would most likely defer to this exercise of jurisdiction provided that by so doing no significantly harmful internal effects result.

It is impossible to state the boundaries of "limited jurisdiction," but these boundaries can be determined on a case-by-case basis. As an illustration, suppose a U.S. based corporation creates a new drug that shows considerable promise for treating certain illnesses, but also has significant side effects. After testing the drug, the United States determines that it is too dangerous and therefore unsafe for use. The United States then forbids production and distribution within the United States. It also prohibits the corporation's foreign branches from producing or selling the drug abroad. This hypothetical approaches the boundaries of "limited jurisdiction" because many foreign states have their own standards and agencies for testing new drugs, and may be opposed to the imposition of U.S. safety standards on companies acting within their territories. Despite their conflicting beliefs concerning the safety of the underlying drug, however, most states probably would not object to this exercise of jurisdiction over foreign branches. One reason why states would not object is that foreign branches are viewed as closely analogous to foreign nationals, and under the nationality principle a state may exercise jurisdiction over its nationals outside of its territory. A foreign branch could also be ordered (by its controlling body) to leave the objecting state. Another reason is that the prohibition would be directed only to the foreign branch, and would not interfere with the ability of other companies to distribute the drug.

The first sentence of subsection (2) accurately restates current international law concerning jurisdiction over foreign subsidiaries: A state may not ordinarily exercise jurisdiction over subsidiaries incorporated in a foreign State on the basis of control or ownership by nationals of the state exercising jurisdiction. ${ }^{53}$ The main reason for this view is that incorporation is a voluntary choice that confers specific benefits on the shareholders. Foreign incorporation results in the subsidiary being treated as a national of the foreign State. Such treatment protects shareholders of the parent

52. Id. $\S 414[418](1)$ (emphasis added).

53. Id. $\S 414[418](2)$. 
company from financial liability and shields them from orders of the foreign State. It also entitles the subsidiary to the protection of local laws. In exchange for treating the subsidiary as its own national, the foreign State is justified in expecting the home state to relinquish its primary jurisdiction.

The home state, however, often will not want to relinquish its primary jurisdiction, preferring to retain as much control as possible. If given a choice, most home states would prefer (although they cannot compel) a parent company to set up a foreign branch instead of a subsidiary, enabling the home state to treat that entity as its own national. In addition, although a subsidiary may operate as a distinct unit, in most cases it is not a completely independent entity. Parental control frequently dictates the course of action the subsidiary must follow. By exercising control, the parent may be able to accomplish objectives that are illegal under the laws of the parent's state. For example, it is illegal for Delaware corporations to operate gambling casinos in Delaware. ${ }^{54}$ A Delaware corporation, however, could set up a subsidiary in the Bahamas to conduct gambling there. ${ }^{55}$ This would enable the subsidiary to conduct a casino business even though gambling is illegal under the laws of the parent company's state of incorporation. Therefore, some limited exercises of jurisdiction by the home state are desirable.

Section (2)(b) is the most controversial; no international consensus about this type of jurisdiction exists. It provides that exercising limited jurisdiction over foreign subsidiaries is not "unreasonable." 56 Paragraph (b) provides a nonexclusive list of factors a state should consider before exercising jurisdiction. Courts should also use these factors to evaluate the reasonableness of the state's action. ${ }^{57}$ This section, however, also emphasizes the need for limitations on home state jurisdiction by stating that it should be exercised only in "exceptional cases." 58

Additional limitations on home state jurisdiction are contained in each of the factors listed in paragraph (b). Subparagraph (i) states that a home state may issue a regulation only if that regulation is an essential element in the furtherance of a major, urgent national interest. ${ }^{59}$ Thus, except in rare circumstances, a state should not assert jurisdiction over subsidiaries as part of the state's general foreign policy. Foreign subsidiaries are not foreign branches, despite the fact that they are owned or controlled by the home state's parent company. The drafters also stress this point in subparagraph (ii), which directs the state to consider whether there are any alternative means of effectively accomplishing the objectives of the state's national

54. See Del. Code AnN. tit. $11, \S 1403$ (1979).

55. Gambling houses may be set up in the Bahamas with permission of the Governor. See STAT. L. OF THE BaHAMa Islands ch. $48, \S 257$ (1) (1965).

56. The section states that "it may not be unreasonable for a state to exercise limited jurisdiction." Restatement (Revised), supra note $2, \S 414[418]$ (2)(b).

57. Id. $\S 414[418](2)(\mathrm{b})$.

58. Id. (emphasis added).

59. Id. \$ $414[418](2)(\mathrm{b})(\mathrm{i})$. 
plan. ${ }^{60}$ However, this subparagraph may be superfluous because a state is not likely to risk an international controversy if it could accomplish the same objectives without exercising jurisdiction. Nevertheless, this factor does force the state to consider other options. It also emphasizes the exceptional circumstances required to justify the exercise of jurisdiction.

Finally, subparagraph (iii) directs attention to whether exercising jurisdiction would conflict with the laws or policies of the state where the subsidiary is established. ${ }^{61}$ Directing the state to consider other states' policies is significant; the potential for conflict with other states' policies is substantially greater than the potential for conflict with laws only. Good faith adherence to the requirements of this subparagraph places significant limitations on the exercise of subsidiary jurisdiction because it prohibits a state from exercising jurisdiction where such exercise would cause the subsidiary to take actions contrary to established policies of the foreign State. The comments to this subparagraph only direct the state to consider the "clearly expressed policy of the [foreign] state."62 Because this section is designed to avoid conflict between states, however, the spirit of section 414 [418], suggests that a state should also consider the unexpressed policies of the foreign States.

The actions of the United States in the Soviet pipeline incident failed to satisfy the requirements of section 414[418]. The attempted extension of jurisdiction over the subsidiaries of U.S. parent companies was not an "exceptional case." There was nothing unique about the situation. The trade embargo was an ordinary foreign policy action. In fact, a foreign state might respond to such an action by issuing similar directives to its own nationals. The attempt by the United States to inhibit completion of the Soviet pipeline through the trade embargo was a symbolic response designed to express the displeasure of the United States with Soviet actions in Poland. ${ }^{63}$ When the embargo was extended on June 22, 1982, President Reagan stated that the "objective of the United States in imposing the sanctions has been and continues to be to advance reconciliation in Poland. Since December 30, 1981, little has changed concerning the situation in Poland; there has been no movement that would enable us to undertake positive, reciprocal measures." 64 Symbolic political actions do not qualify as exceptional cases in which it would be appropriate to exercise jurisdiction because they frequently have extended and uncertain effects. It is highly unlikely that the United States believed the Soviets would decrease their influence in Poland even if foreign subsidiaries fully cooperated.

Moreover, the trade embargo was imposed because of the economic implications that the pipeline had for the Soviet Union and the political

60. Id. $\S 414[418](2)(\mathrm{b})$ (ii).

61. Id. $\$ 414[418](2)(\mathrm{b})(\mathrm{iii})$.

62. Id. comment d.

63. See Note, Dresser Industries, supra note 23, at 135, 139-41.

64. President's Statement on Extension of U.S. Sanctions, 18 WeEkly Comp. Pres. Doc. 820 (June 18, 1982). 
implications it had for Western Europe. The Soviet Union is unable to produce enough food to feed its population, and is incapable of exporting a sufficient amount of manufactured goods to buy the necessary food, technology, and other goods. Because of this trade imbalance, the Soviet Union has problems generating enough foreign currency to sustain its import purchases. ${ }^{65}$ Nevertheless, the Soviet Union has over forty percent of the known world gas reserves. ${ }^{66}$ These considerations led to the imposition of the embargo. As one commentator noted:

The Reagan Administration . . . [saw the Soviet-European pipeline as] an agreement which will provide the Soviet Union with substantial hard currency earnings that will help ease the burden of expanded military spending, or at least ease the rate at which that burden is growing. There is also a general concern that a Europe dependent on the USSR for 5 percent of its total energy supplies will be a Europe ever so slightly more willing to see the Soviet side in the great-power rivalry. In addition, the Reagan administration is bothered by the symbolism involved in the conclusion of a significant agreement between the Soviet Union and Europe when in the space of four years the Soviets invaded one country and crushed a grass-roots mass political movement in another. ${ }^{67}$

This explanation for the embargo does not present sufficient justification for the exercise of subsidiary jurisdiction; it does not transform the actions of the United States into the type of "exceptional case" contemplated by section 4 14[418](2). The United States for many years attempted to retard the Soviet military buildup and prevent enhanced Soviet-European relationships. Furthermore, the Soviet Union had been negotiating agreements concerning the pipeline with Europe for a number of years.

One major shortcoming of section 414[418] is that it fails to explain what situations qualify as "exceptional." It seems clear that direct U.S. involvement in a war or the imminent threat of such involvement would satisfy the exceptionality requirement. Short of these two occurrences, however, it is questionable whether any other circumstances would suffice. Although the drafters wanted to emphasize that jurisdiction over foreign subsidiaries is an extraordinary action, their failure to define "exceptional circumstances" makes the section difficult to apply.

An evaluation of the Soviet pipeline incident under the relevant factors listed in paragraph (2)(b) shows that the actions of the United States were unreasonable. The trade embargo was not implemented to further a "major, urgent national interest."68 If the reasons given by the United States are taken at face value, the national interests of Poland and not those of the United States were at stake as a result of Soviet activity. Section 414[418] makes no allowance for the use of subsidiary jurisdiction to promote the national interests of other states. This section's authorization of subsidiary jurisdiction as a means of furthering the national interest of the state exercising jurisdiction is controversial enough; embracing the national

65. Hewett, The Pipeline Connection: Issues for the Alliance, Brookings Rev., Fall 1982, at 15, 19.

66. Id. at 15 .

67. Id. at 19-20.

68. RESTATEMENT (Revised), supra note 2, § 414[418](2)(b)(i). 
interests of other states would only heighten the controversy. Furthermore, there were no urgent U.S. national interests at stake. Poland, the pipeline, and the Soviet military buildup were relatively long-standing situations with no immediate resolution in sight. Because the exercise of jurisdiction by the United States was not "essential," its actions as analyzed under subparagraph (i) were not reasonable.

Subparagraph (ii) focuses attention on whether the exercise of jurisdiction over the subsidiary is necessary for effective completion of the national program. ${ }^{69}$ Evaluation of this factor is somewhat difficult because of the uncertainty concerning the purpose of the embargo. However, because the purpose of the plan was to "advance reconciliation" in Poland, ${ }^{70}$ and to impair completion of the pipeline, subsidiary compliance was necessary for an effective embargo.

Finally, subparagraph (iii) requires an evaluation of whether the regulation sought to be applied is in potential or actual conflict with the law or policy of the foreign States. ${ }^{71}$ Europe refused to join in an embargo previously proposed by the United States against the Soviets because of Soviet activity in Poland. ${ }^{72}$ This refusal provides strong evidence that subsidiary compliance with the embargo would directly conflict with the policies of other states. Furthermore, the active involvement of European governments in the promotion and completion of the pipeline reflected Europe's position: it wanted both the gas from the pipeline and the income from the pipelinerelated exports to the Soviet Union. The attempted interference by the United States with completion of the pipeline through the embargo was therefore in actual conflict with the policies of the states in which subsidiaries were established.

Subparagraph (iii) mandates a consideration of both the actual and the potential conflicts that may arise as a result of exercising jurisdiction over a foreign subsidiary. Although the embargo did not conflict with any current foreign laws, the United States should have known that foreign States might pass laws compelling subsidiaries to violate the embargo orders and complete delivery contracts with the Soviets. The European states' earlier refusal to participate in an embargo and their support for the pipeline shows that subsidiary compliance would cause conflicts. The existence of these conflicts makes the actions of the United States unreasonable under subparagraph (iii).

Thus, analysis of the pipeline incident under section 414[418] shows that the United States acted unreasonably. The surrounding situation was not an "exceptional case" justifying the exercise of extraterritorial subsidiary jurisdiction, and the actions of the United States failed to satisfy the requirements of two out of three subparagraphs in section 414[418](2)(b). As a result, the United States should not have exercised jurisdiction.

69. See supra note 60.

70. See supra President Reagan's statement in the text accompanying note 64 .

71. See supra note 61 .

72. See Note, Extraterritorial Application, supra note 11, at 364 . 
This conclusion is consistent with part II's conclusion that the United States was not justified in exercising jurisdiction over foreign subsidiaries. That both analyses produce the same result supports the argument that section $414[418]$ is a viable basis for analyzing the exercise of jurisdiction by the United States over foreign subsidiaries. While section 414[418] provides a compelling analysis where the exercise of jurisdiction is inappropriate, to be complete section 414[418] must reach the same result where the exercise of jurisdiction is appropriate. Unfortunately, there has not been an internationally accepted exercise of subsidiary jurisdiction to test whether analysis under that section would also produce a consistent result.

In summary, an analysis of section 414[418] shows that it provides a fairly narrow basis for exercising subsidiary jurisdiction. Any exercise of jurisdiction over foreign subsidiaries is controversial, and the section contains significant limitations on a state's right to exercise that jurisdiction. Strict adherence to the limiting language contained in the section will reduce the potential for controversy and promote acceptance of subsidiary jurisdiction by foreign states and international tribunals. In fact, a strict adherence to the language of section 414[418] may even produce results that are more restrictive of conduct than is desirable. Given the tense international situation, however, it may prove wiser to impose greater limitations than necessary on the exercise of jurisdiction.

\section{IV}

\section{Receptiveness of European Countries to Subsidiary Jurisdiction and the Long-term Treaty SOlution}

Europeans have criticized the extensions of U.S. jurisdiction over foreign subsidiaries, ${ }^{73}$ but it is clear that the predominant European view, based primarily on the territorial principle, is too narrow. The desire to focus on strictly territorial considerations and to adhere rigidly to the idea of complete corporate separateness fails to provide a viable solution to the extraterritoriality problem. The world has become so interconnected and interdependent that primary reliance on the territorial principle is unrealistic. Foreign subsidiaries have played a significant role in establishing these international connections, and international agreement on proper jurisdiction over these subsidiaries is needed to promote stability. Unfortunately, largely as a result of the Soviet pipeline incident, it is no longer possible to obtain a general international consensus. Feelings of hostility and the quest for selfprotection have replaced the spirit of cooperation. The uncertainty surrounding future exercises of extraterritorial subsidiary jurisdiction has also created great uneasiness among Europeans. ${ }^{74}$ In addition, there are inherent

73. See Havers, supra note 43 , at 786 .

74. Id. 
shortcomings in relying on national judiciaries to establish the basic principles. ${ }^{75}$

Although individual European countries have voiced opposition to extraterritorial jurisdiction over subsidiaries, ${ }^{76}$ their collective action in their own multistate interactions shows an implicit acceptance of the idea that wholly owned or controlled subsidiaries are not completely independent entities. The Commission of the European Communities and the Court of Justice of the European Community have developed an approach to multistate interactions known as the "economic unit" theory. ${ }^{77}$ The economic unit theory ignores the separate legal status of parent and subsidiary corporations and treats the two as one united entity for purposes of establishing jurisdiction. The net result of the establishment of jurisdiction is the strong potential for the imposition of liability.

The economic unity theory was first applied by the Court of Justice of the European Community in Imperial Chemical Industries, Ltd. v. E.C. Commission. ${ }^{78}$ In that case, the Commission challenged a price increase instituted by eighty percent of the Community dyestuff producers. Imperial Chemical Industries, Ltd. (ICI) argued that the court had no jurisdiction over the applicants because the applicants' registered offices ${ }^{79}$ were outside the Common Market. The court dismissed this argument and held that it had jurisdiction because ICI was within the Common Market. The court offered the following explanation:

The fact that a subsidiary has a distinct legal personality does not suffice to dispose of the possibility that its behavior might be imputed to the parent company . . . with which it then forms one economic unit. . . In these circumstances, the formal separation between these companies . . . cannot, for the purposes of application of the competition rules, prevail against the unity of their behavior on the market. ${ }^{80}$

In reaching its decision to exercise jurisdiction, the court stressed ICI's control over the subsidiary. The court noted that ICI held the whole or a majority of the capital of these subsidiaries. However, additional language in the opinion suggested that control alone might not be sufficient to impute the subsidiary's conduct to its parent. Rather, the opinion suggested that

75. See, e.g., A. Hermann, Conflicts of National Laws with International Business ACtivity: Issues of Extraterritoriality 4-5 (1982). Laker Airways Ltd. v. Sabena, 731 F.2d 909 (D.C. Cir. 1984) (Judge Wilkey focused on the directives of the United States government and would not perform an independent balancing of the international issues).

76. See supra notes 24,45 .

77. The Commission and the Court have used this theory in cases brought under Articles 85 and 86 of the Treaty of Rome which contain the competition (antitrust) laws for the European Economic Community (EEC). See Treaty Establishing the European Economic Community, entered in force Jan. 1, 1958, art. 85, 298 U.N.T.S. 11; Treaty Establishing the European Economic Community, entered in force Mar. 25, 1957, art. 86, 295 U.N.T.S. 2. For an excellent discussion of the economic unit theory, see B. Barack, The Application of the Competition Rules (Antitrust law) of the European Economic Community to Enterprises and Arrangements External. to the Common Market 5373 (1982).

78. Imperial Chem. Indus. v. E.C. Comm'n, 11 Common Mкт. L. ReP. 557 (1972) (the "Dyestuffs case").

79. This is equivalent to the place of incorporation.

80. Imperial Chem. Indus. v. E.C. Comm'n, 11 Common MKт. L. Rep. 557, 629 (1972). 
imputation of the conduct of the subsidiary to the parent was appropriate when the subsidiary "does not determine its behavior on the market in an autonomous manner but essentially carries out the instructions given to it by the parent company." 81 After dismissing ICI's jurisdictional argument, the court proceeded to affirm the Commission's finding that ICI had violated EEC competition laws and the Commission's consequent imposition of liability.

The subsequent cases have focused more on the percentage of capital owned and less on the extent to which control is exercised. ${ }^{82}$ In fact, in later decisions in which the Court of Justice of the European Community exercised jurisdiction, the parent company owned a smaller percentage of capital than that owned by ICI. ${ }^{83}$ Moreover, both the court and the Commission have been willing to imply actual control in cases in which the parent company owned a majority of the stock or capital, reasoning that majority ownership gives the parent the power to control. ${ }^{84}$ The court has never exercised jurisdiction, however, in cases in which the parent owned less than a majority of the subsidiary's capital. ${ }^{85}$

In many cases, the use of a percentage-ownership test as the sole criterion for proof of control will produce the same conclusion (with respect to the existence of control) as the court would have reached had it considered the presence or absence of other indicia of control. Nevertheless, focusing solely on percentage ownership is undesirable because it eliminates the possibility of treating a truly independent subsidiary differently. One could argue that the power to exercise control and actually exercising it are two different things. It is difficult to quantify parental control, but the parent and subsidiary should have the option of proving that the parent did not exercise control despite the fact that it owned a majority of the capital. A counter argument is that, as a practical matter, majority ownership gives the parent the power to control. Whether this power is actually exercised should not be determinative of the existence of jurisdiction. Nevertheless, it is particularly useful to allow a company to demonstrate absence of control in situations where the parent had no advance knowledge of the subsidiary's activities, and would not have authorized these activities if it knew about them. This scenario is quite possible where a parent's subsidiary is managed and operated solely by individuals within a foreign state. Unfortunately, no EEC decisions provide a

81. Id.

82. See infra text accompanying notes 86-92.

83. See infra note 91 and accompanying text (fifty-one percent ownership was sufficient).

84. See infra text accompanying notes 86-92.

85. There are two explanations for the court's emphasis on both capital ownership and the exercise of control by the parent company. First, the court may have stressed the need for both to provide additional justification for the new and somewhat radical economic unit theory. As it has grown more comfortable with the theory, it may fecl that both elements are no longer necessary. Second, it may have wanted to leave open the option of using the economic unit theory in situations where a parent exercised control but did not own a majority of the subsidiary's capital or stock. Unfortunately, subsequent cases have not provided an answer to the question of whether control alone (and no majority ownership) would suffice. 
clear answer as to whether majority ownership would be sufficient if the company could show that the parent had no control over the subsidiary.

In Europemballage Corp. and Continental Can Company, Inc. v. E.C. Commission, ${ }^{86}$ the Court of Justice of the European Community used the parent-subsidiary relationship to establish jurisdiction over the American parent, Continental Can Company. The court, using language similar to that in Imperial Chemical, stressed the lack of autonomous market behavior. It also stressed that Europemballage Corp. followed instructions from the parent to make an offer to buy the shares of a company in the Netherlands and that the parent provided the necessary funds. ${ }^{87}$ The court made it clear that the "fact that Continental Can does not have a seat in the territory of one of the member states does not suffice to remove it from the jurisdiction of community law."'88

The Court of Justice of the European Community also used the economic unit theory in Instituto Chemioterapico Italiano SpA and Commercial Solvents Corp. $v$. E.C. Commission. ${ }^{89}$ The court summarily approved the Commission's finding that at least with respect to the plaintiff Zoja, Commercial Solvents Corp. (Commercial) and its subsidiary Instituto Chemioterapico Italiano SpA (Instituto) acted as one economic unit. ${ }^{90}$ The Commission's decision, however, shows that fewer indicia of control were required in this case than in previous cases to support the conclusion that the two were a single economic unit.

The Commercial Solvents Corp. holds controlling power over Istituto Chemioterapico since it holds 51 percent of its share capital, which permits it to exercise permanently a determining action over the formation of the corporate will and thus over the management of Istituto Chemioterapico, given that the general meeting, by the favourable vote of a number of shareholders representing more than the majority of the share capital, has inter alia the power to appoint the directors, to discuss their responsibilities to approve the balance sheet. . . It may then be concluded that the Commercial Solvents Corp. holds the power of control over Istituto Chemioterapico and exercises it in fact, at least as regards its relations with Zoja. ${ }^{91}$

Therefore, that Commercial's fifty-one percent ownership gave it the power to exercise control was sufficient to establish jurisdiction over the subsidiary, and consequently liability was imposed. Jurisdiction did not depend on Instituto's failure to exhibit any "autonomous market activity."92 It was sufficient that the two corporations apparently acted as a single economic unit in dealing with Zoja. The court's subsequent failure to scrutinize these findings with respect to control shows tacit consent to the Commission's approach, and

86. Europemnballage Corp. v. E.C. Comm'n, 12 Common Mkt. L. ReP. 199 (1973).

87. Id. at 221.

88. Id. at 222 .

89. Instituto Chemioterapico Italiano SpA v. E.C. Comm'n, 13 Common Mкт. L. ReP. 309 (1974). For an in-depth discussion of this case, see Bentil, Control of the Abuse of. Monopoly Pouter in EEC Business Law, 12 Common Mkt. L. Rep. 59 (1975).

90. Instituto Chemioterapico Italiano SpA v. E.C. Comm'n, 13 Comm. Mkt. L. R. 309, 342-44 (1974).

91. Laboratorio Chimico Farmaceutico Giorgio Zoja SpA v. Commercial Solvents Corp., 12 Сомmon Mкт. L. ReP. D50, D56-57 (1973).

92. See supra text accompanying notes $80-81$. 
indicates that mere power to exercise control, as opposed to actual control, will suffice to establish jurisdiction.

In these cases, the Court of Justice of the European Community exercised jurisdiction over the controlling parent because the subsidiary had engaged in illegal activities within the court's jurisdiction. This situation differs from obtaining jurisdiction through a controlling parent over a subsidiary in a foreign jurisdiction. Although the two situations are not identical, the key element in both cases is the parent's ability to control its subsidiary. In the EEC opinions, the establishment of jurisdiction and subsequent imposition of liability in two of the three was implicitly based on one or both of these theories: (1) The parent directly exercised its control over the subsidiary and ordered it to commit the illegal acts; or (2) the parent failed to exercise its control to prevent the subsidiary from violating the law. Under both theories, the ability to control the subsidiary was the basis for both the exercise of jurisdiction and the imposition of liability. The claim of the United States to jurisdiction over foreign subsidiaries is based on the same criterion. In fact, the court's position is even more extreme because it uses control both as a means to exercise jurisdiction and to impose financial liability. This imposition of financial liability is far-reaching because the court pierced the corporate veil even though the entities were separately incorporated. The court's justification for finding liability was the parent's ability to control the subsidiary. These EEC cases show that Europeans have recognized that it is necessary to exercise intracorporate jurisdiction in some multistate interactions.

The courts, however, are ill-suited to formulate acceptable international standards for extraterritorial subsidiary jurisdiction. ${ }^{93}$ One plausible solution is for the United States to negotiate treaties with European countries. Treaties may also promote greater cooperation from foreign States in the application and enforcement of extraterritorial legislation. Although one multilateral treaty would be ideal, it is more realistic to expect negotiation of bilateral treaties. Moreover, bilateral treaties would be advantageous because they would enable both states to tailor the treaty to satisfy their particular concerns. The provisions of section 414[418] would provide a good starting point for negotiations. It is particularly important that these negotiations determine the extent of ownership or control that states would agree to recognize as sufficient for the exercise of jurisdiction. One drawback to the treaty solution is that negotiation is a slow and time consuming procedure. Nevertheless, the treaty option is the most feasible one in light of the pressing need for such agreements and the absence of a general international consensus concerning the proper scope of extraterritorial subsidiary jurisdiction.

The United States should therefore begin negotiations with the European countries concerning the exercise of jurisdiction over foreign subsidiaries.

93. See supra text accompanying notes 74-75. 
There are already precedents for this in the antitrust area where the United States has signed agreements with the Federal Republic of Germany and Australia. ${ }^{94}$ The United States State Department and heads of foreign States may at first resist these treaties because they prefer the flexibility of handling each situation as it arises, but the need for greater certainty in multinational economic transactions and the need for cooperation from foreign States outweigh the benefits of ad hoc treatment. The United States may also resist the treaty mechanism on the ground that it has no incentive to enter into treaties limiting its ability to exercise extraterritorial jurisdiction. The United States lacks such an incentive because it has always been primarily a capital exporter. As a result of its trade position, the United States has traditionally been the state extending jurisdiction rather than the object of an extraterritorial extension of jurisdiction by another state. This argument, however, only considers the current trade position of the United States. As the U.S. economy becomes more internationalized, the position of the United States will change. Before long, the United States may find itself affected by extraterritorial extensions of jurisdiction. Thus, although treaties may immediately limit the United States, the greater certainty and stability these treaties will provide will be of value in the future.

Section 414[418] of the Restatement (Revised) would provide a viable model for international negotiations. It presents an approach that satisfies the conflicting needs of providing the home state with limited jurisdiction over foreign subsidiaries and protecting the foreign State's jurisdictional powers. Section 414[418] achieves this result by authorizing only limited exercises of subsidiary jurisdiction in exceptional cases. ${ }^{95} \mathrm{~A}$ good faith effort by two states to strictly adhere to the limiting language contained in section 414 [418] would produce a workable compromise. That both states would have reciprocal rights under the treaty also helps assure that neither would abuse its jurisdictional power.

\section{$\mathrm{V}$}

\section{The Interim Solution: Notification and Consultation}

Negotiating treaties as a means of establishing guidelines for subsidiary jurisdiction requires considerable time and energy. There is a strong need for an interim solution that would bridge this gap. The Organization for Economic Co-operation and Development's (OECD's) notification and consultation procedures ${ }^{96}$ provide an excellent model which states could easily adapt to the subsidiary jurisdiction context.

94. See Agreement Between the Government of the United States of America and the Government of Australia Relating to Cooperation on Antitrust Matters, 21 INT'L Legal Materials 702 (1982) (signed June 29, 1982); Federal Republic of Germany-United States: Agreement Relating to Mutual Cooperation Regarding Restrictive Business Practices, 15 INT'L Legal Materials 1282 (1976) (entered into force Sept. 11, 1976).

95. See supra text accompanying notes 90-91

96. See Organisation for Economic Co-operation and Development, The 1984 Review of THE 1976 DECLARATION AND DECISIONS 25-27 (1984) which provides: 
Although the OECD's procedures focus on extensions of jurisdiction to the activities of multinational enterprises abroad, the basic principles address concerns relevant to subsidiary jurisdiction. The extending state must first notify the affected state that it is contemplating an extraterritorial exercise of jurisdiction. ${ }^{97}$ This procedure is ideal because it allows the extending state to receive feedback and to evaluate the concerns of the affected state before it has committed itself to a particular course of action. It also enables the extending state to incorporate any suggestions for alternative solutions. The drafters of the procedures recognized, however, that advance notification will not always be feasible. The language therefore states that notification should occur "as soon as practicable." 98 The use of the word "practicable" instead of one like "possible" acknowledges that a state may have security or other compelling reasons for not providing the earliest possible notification in all

(a) General Considerations

27. In contemplating new legislation, action under existing legislation or other exercise of jurisdiction which may conflict with the legal requirements or established policies of another Member country and lead to conflicting requirements being imposed on multinational enterprises, the Member countries concerned should:

i) Have regard to relevant principles of international law;

ii) Endeavour to avoid or minimise such conflicts and the problems to which they give rise by following an approach of moderation and restraint, respecting and accommodating the interests of other Member countries (21);

iii) Take fully into account the sovereignty and legitimate economic, law enforcement and other interests of other Member countries;

iv) Bear in mind the importance of permitting the observance of contractual obligations and the possible adverse impact of measures having a retroactive effect.

28. Member countries should endeavour to promote co-operation as an alternative to unilateral action to avoid or minimise conflicting requirements and problems arising therefrom. Member countries should on request consult one another and endeavour to arrive at mutually acceptable solutions to such problems.

(b) Practical Approaches

29. [omitted]

30. Member countries should therefore be prepared to:

i) Develop mutually beneficial, practical and appropriately safeguarded bilateral arrangements, formal or informal, for notification to and consultation with other Member countries;

ii) Give prompt and sympathetic consideration to requests for notification and bilateral consultation on an ad hoc basis made by any Member country which considers that its interests may be affected by any measure of the type referred to under paragraph 27 above, taken by another Member country with which it does not have such bilateral arrangements;

iii) Inform the other concerned Member countries as soon as practicable of new legislation or regulations proposed by their Governments for adoption which have significant potential for conflict with the legal requirements or established policies of other Member countries and for giving rise to conflicting requirements being imposed on multinational enterprises;

iv) Give prompt and sympathetic consideration to requests by other Member countries for consultation in the CIME or through other mutually acceptable arrangements. Such consultations would be facilitated by notification at the earliest stage practicable;

v) Give prompt and full consideration to proposals which may be made by other Member countries in any such consultations that would lessen or eliminate conflicts.

These procedures do not apply to those aspects of restrictive business practice or other matters which are the subject of existing OECD arrangements.

97. Id. at 26 (paragraph 27).

98. Id. at 26-27 (paragraph $30($ iii)). 
cases. Notification provisions therefore incorporate a realistic compromise and recognize the competing policy considerations of each state.

The consultation provisions also promote interaction between the states and emphasize the duty of the extending state to give prompt and full consideration to proposals made by the affected state. ${ }^{99}$ One goal of the procedures is to minimize conflicts between states. ${ }^{100}$ Establishing and maintaining open communication between extending and affected states is essential to achieving this goal. It is true that situations will arise that cannot be resolved by negotiation, but consultation may reduce the negative impact of unilateral action.

An example using the facts of the Soviet pipeline incident will show how the United States could have employed notification and consultation procedures. Prior to the issuance of regulations on June 22, 1982, the United States could have privately notified the governments of European states that it was contemplating issuing regulations to prevent the re-export of gas and pipeline equipment and technology to the Soviet Union. The United States could then have given these states an opportunity to comment on the regulations and propose alternatives or suggestions. For example, the European states might have emphasized the importance of a grandfather clause to prevent breaches of existing contracts. ${ }^{101}$ It is likely that the European states would have also expressed their strong opposition to the regulations. Perhaps they would have made it clear that they would take whatever action was necessary to prevent the success of the embargo. This interaction might have led the United States to create a plan that the European states would have supported. In addition, the United States would have had more information with which to make a decision concerning the regulations. This information might have led the United States to realize that the embargo would not succeed, and that its implementation through the regulations would only antagonize our allies. The United States could then have decided whether it nonetheless wanted to issue the regulations, but it probably would not have issued them. The advance notification, consideration of European proposals, and the justifications offered by the United States for its actions might have produced a more favorable response by the European states. At a minimum, the European states would not have been surprised by the regulations and could have taken steps to reduce losses.

Adopting notification and consultation procedures would also produce other significant benefits. It would help reduce the international tensions that have developed in response to recent extraterritorial exercises of jurisdiction. In particular, it would demonstrate a willingness on the part of extending states to consider the rights of affected states. The good faith employment of notification and consultation procedures would ameliorate feelings of hostility and self-protection, and would help foster the development of greater

99. Id. at 27 (paragraph $30(\mathrm{v})$ ).

100. Id. at 26 (paragraph 27 (ii)).

101. See supra text accompanying note 26 . 
cooperation among states. Cooperation is necessary for successful treaty negotiations. Even when the affected state and the extending state are unable to resolve their differences, advance notification would enable the affected state to prepare for the consequences of the proposed action. ${ }^{102}$ The United States has already established a notification and consultation agreement concerning antitrust matters with Canada, ${ }^{103}$ and in 1985 adopted notification and consultation requirements for the imposition of export controls by the United States. ${ }^{104}$ This latter action by the United States should receive warm international praise and produce a commendable result. It should also act as an initiative to other states to adopt similar provisions.

\section{VI \\ Conclusion}

The world has reached an impasse in the area of subsidiary jurisdiction. The apparent view of the United States that all subsidiaries owned or controlled by American nationals are functionally identical to United States corporations is too broad. Because of the tension pervading this area, it appears that an acceptable compromise will require the negotiation and signing of a number of bilateral treaties. The process of negotiation alone will help alleviate the perception of European states that the United States believes it may exercise extraterritorial jurisdiction without recognizing similar exercises by foreign states.

The provisions of section 414[418] of the Restatement (Revised) would provide a good starting point for the treaty negotiations. The language of section 414[418] emphasizes that states should exercise jurisdiction over foreign subsidiaries only in limited and exceptional cases. This is consistent with the current needs of international law. In many instances, states should recognize that parents and their subsidiaries are separate entities. There are an increasing number of cases, however, where this view ignores the realities of parental power to control its subsidiary. The analysis suggested by section 414 [418] properly considers both of these competing needs. The one major flaw of the section is that it does not focus on the amount of control required to justify the exercise of jurisdiction. The approach of the Court of Justice of the European Community in Imperial Chemical Industries, Ltd. would provide a good model for resolution of the control problem. In reaching its decision,

102. This will produce only a negligible benefit in situations where notification was given only shortly before implementation.

103. Memorandum of Understanding Between the Government of the United States of America and the Government of Canada as to Notification, Consultation and Cooperation with Respect to the Application of National Antitrust Laws, 23 InT'L Legal Materials 275 (1984) (signed Mar. 9, 1984).

104. Export Administration Amendments Act of 1985, Pub. L. No. 99-64, § 108(d), 99 Stat. 131 (to be codified at 50 U.S.C. $\$ 2405$ (Supp. III 1985)). The new section reads:

Consultation with Other Countries.-When imposing export controls under this section, the President shall, at the earliest appropriate opportunity, consult with the countries with which the United States maintains export controls cooperatively, and with such other countries as the President considers appropriate, with respect to the criteria set forth in subsection (b)(1) and such other matters as the President considers appropriate. 
the court did not look solely at the percentage of stock ownership. Instead, it also considered the amount of control actually exerted by the parent over the subsidiary. ${ }^{105}$ This approach properly balances the parent's power to control and the subsidiary's independent existence. An important part of the treaty negotiations will be to establish standards or tests for determining control.

During the interim prior to completion of the treaty process, other states should follow the United States' example of adopting notification and consultation procedures. The purpose of these procedures is to provide foreign States with as much advance notice of an extraterritorial extension of jurisdiction as is practical. Ideally, notification would occur early enough to allow feedback from the affected state. The extending state could then incorporate any suggestions made or at least make its decisions with greater knowledge of the potential ramifications. Notification and consultation procedures should reduce international tensions because they evidence a willingness on the part of the extending state to consider the potential consequences of its actions within foreign States.

105. The court may have required greater indicia of control in this case because the parentsubsidiary link was used as the basis for imputing direct financial liability. See supra note 78. 
